\title{
Hydrochemical Evolution in Ciliwung River - Java, Indonesia: Study of Sea Water Mixture and Mineral Dissolution
}

\author{
Evarista Ristin Pujiindiyati ${ }^{1,}$, Paston Sidauruk $^{1}$, Tantowi Eko Prayogi ${ }^{2}$, and Faizal Abdillah ${ }^{2}$ \\ ${ }^{1}$ Center for Isotopes and Radiation Application - National Nuclear Energy Agency, \\ Jl. Lebak Bulus Raya No. 49, Jakarta 12440, Indonesia \\ ${ }^{2}$ Groundwater Conservation Center, Geological Agency, Ministry of Energy and Mineral Resources, \\ Jl. Tongkol No. 4 Pademangan, Jakarta Utara 14430, Indonesia
}

\author{
*Corresponding author: \\ email: ristinpi@batan.go.id \\ Received: October 28, 2019 \\ Accepted: March 10, 2020 \\ DOI: $10.22146 / \mathrm{ijc} .50962$
}

\begin{abstract}
The chemical characteristics of the Ciliwung River were analyzed to understand hydrochemical evolution. A fraction of sea water mixture and kinds of mineral controlling for chemicals were also determined. During three year investigations in 2015, 2016, and 2018, electrical conductivity increased with decreasing elevations. Two hydrochemical facies had been identified for the Ciliwung river water; those were $\mathrm{Ca}-\mathrm{Mg}$ $\mathrm{HCO}_{3}$ and $\mathrm{Ca}-\mathrm{Na}-\mathrm{HCO}_{3}$. The river water mixing with seawater was recognized in the Mangga Dua site in which its water type had shifted to $\mathrm{Na}-\mathrm{Ca}-\mathrm{HCO}_{3}-\mathrm{Cl}$. Based on $\mathrm{Na}-\mathrm{Cl}$ contents, the fraction of sea water into the Ciliwung River reached 2\% in the Mangga Dua site during the dry season and decreased to $0.7 \%$ during the rainy season in 2015. The much higher monthly rainfall during the dry season in 2016 and 2018 had washed out invading seawater from the Mangga Dua site; its fraction of sea water was less than $0.4 \%$. Saturation indexes with respect to calcite, dolomite, and gypsum minerals showed an increasing trend related to the decreasing elevations. All water samples were undersaturated with respect to gypsum. Meanwhile, saturation indexes with respect to calcite and dolomite mostly indicated undersaturated, except in the Mangga Dua site that was saturated (during the rainy season in 2015 and dry season in 2018) and supersaturated during the dry season in 2015.
\end{abstract}

Keywords: Ciliwung River; hydrochemical; sea water mixture; saturation index

\section{- INTRODUCTION}

The catchment area of the Ciliwung River is originated from the slope of the Gede Pangrango Mountain (3000 $\mathrm{m}$ above sea level) - West Java. This river flows from mountainous areas to the low land through Bogor, Depok, and empties in Jakarta Bay. The Ciliwung River is the largest, and the most important of thirteen rivers flowing through the coastal region of Jakarta with length from upstream to the estuary is approximately $117 \mathrm{~km}$ and covers an area $387 \mathrm{~km}^{2}$ [1]. Geographically, the Ciliwung catchment area is located at latitude ranges from $6^{\circ} 06^{\prime} 12^{\prime \prime}$ to $6^{\circ} 34^{\prime} 56^{\prime \prime}$ and longitude ranges from $106^{\circ} 47^{\prime} 43^{\prime \prime}$ to $107^{\circ} 0^{\prime} 15^{\prime}$. Flat slope $(8 \%)$ dominates in downstream, whereas the middle area has slope range between $8 \%-$ $15 \%$, and steep slope only occurs in upstream. The catchment area of Ciliwung is bordered by the Cisadane catchment area in the northern part and Citarum catchment area in the eastern part [2-3]. In the Ciliwung catchment area, there is a forested mountainous part in the headwater, urbanized Bogor city area in the middle part and heavily urbanized Jakarta metropolitan area at the lower most part of the catchment [4].

Hydrologically, the flow rate of the Ciliwung River varies depending on the average annual precipitation in a watershed. There are two seasons influencing the amount of precipitation coming from two wind regimes. The northwest monsoon season is the dry season occurring from May to October; the flow rate is low. Meanwhile, the southeast monsoon season is from November to April that is the rainy season; the flow rate 
is very high such that flooding often occurs. The geological condition of the Ciliwung catchment area is formed by volcanic rocks from two volcanic mountains. They are Pangrango Mountain that contains tuff breccia rocks, and Salak Mountain that contains alluvial deposits and alluvial fan. The surface is mostly covered by alluvial deposits comprising soil, sand, and gravel. Those main geological compositions produce the kind of fertile soil. Upstream of Ciliwung is dominated by tertiary sediment and intrusive rock fraction, whereas the type of rock in the middle is precipitated quarter [2,5].

The great importance of the Ciliwung River for Jakarta District had paid some researcher's attention to study for various aspects such as its water quality $[3,4]$, hydrology, and hydrogeology $[1,5,6]$. However, fewer studies about chemicals contained in the Ciliwung River had been reported in the public domain. Irawan et al. [7] concluded that there were closed connections between the river water and groundwater.

Major dissolved chemicals such as $\mathrm{Na}^{+}, \mathrm{K}^{+}, \mathrm{Ca}^{2+}$, $\mathrm{Mg}^{2+}, \mathrm{Cl}^{-}, \mathrm{SO}_{4}{ }^{2-}$ and $\mathrm{HCO}_{3}{ }^{-}$are an important parameter in the investigation of river water formation and geochemical evolution along with the flow. The well understanding of the geochemical evolution of river water is needed for achieving proper management of the important resources and for the protection of river water quality and its river ecology. The most common pathway of geochemical evolution or the introduction of salinity into the freshwater system is an enrichment of salts such as $\mathrm{NaCl}$ and $\mathrm{CaSO}_{4}$ by evaporation, rock weathering, or dissolution of minerals, wash out or flushing of salts by precipitation, cation exchange, mixing of different water and input from anthropogenic sources. However, in a different section of the river, the main processes could be different [8]. The river water formations had become an interesting topic and intensively studied around the world [8-13]. Rothwell et al. [13] studied the spatial and seasonal pattern of river water chemistry in Northwest England and found that there was a clear distinction between uplands and lowlands in water quality.

In this Ciliwung River study, major dissolved ions of $\mathrm{Na}^{+}, \mathrm{K}^{+}, \mathrm{Ca}^{2+}, \mathrm{Mg}^{2+}, \mathrm{Cl}^{-}, \mathrm{SO}_{4}{ }^{2-}$ and $\mathrm{HCO}_{3}{ }^{-}$as well as some physical parameters such as $\mathrm{pH}$, Electrical conductivity
(EC) and temperatures were intensively observed for the periods of 2015, 2016 and 2018. The aims of this study were to understand the signatures of the Ciliwung River system responding to a natural process such as mineral dissolution and sea water mixture.

\section{- EXPERIMENTAL SECTION}

\section{Location and Sampling}

Collecting water samples was conducted in three years of 2015, 2016, and 2018 in which each year was scheduled in two sampling periods, the rainy and dry seasons. Ciliwung River samples were taken at surface water, starting from the upper stream at Telaga Warna Lake in National Park of Gede Pangrango Mountain Bogor - West Java with an elevation around $1485 \mathrm{~m}$ a.s.l to the mouth of Jakarta Bay in Mangga Dua with an elevation around $5 \mathrm{~m}$ a.s.l. Those sites were defined with red points, while the region of the Ciliwung catchment area was defined with the yellow area, as mapped in Fig. 1. Sampling site with its ID codes and its elevations were performed in Table 1. For analysis of cations, as much as $0.5 \mathrm{~L}$ water samples were put in a plastic bottle and added a few drops of $\mathrm{HNO}_{3}$ solution to preserve water samples from precipitation. While for anion analysis, the same amount of water was put in a separate plastic bottle

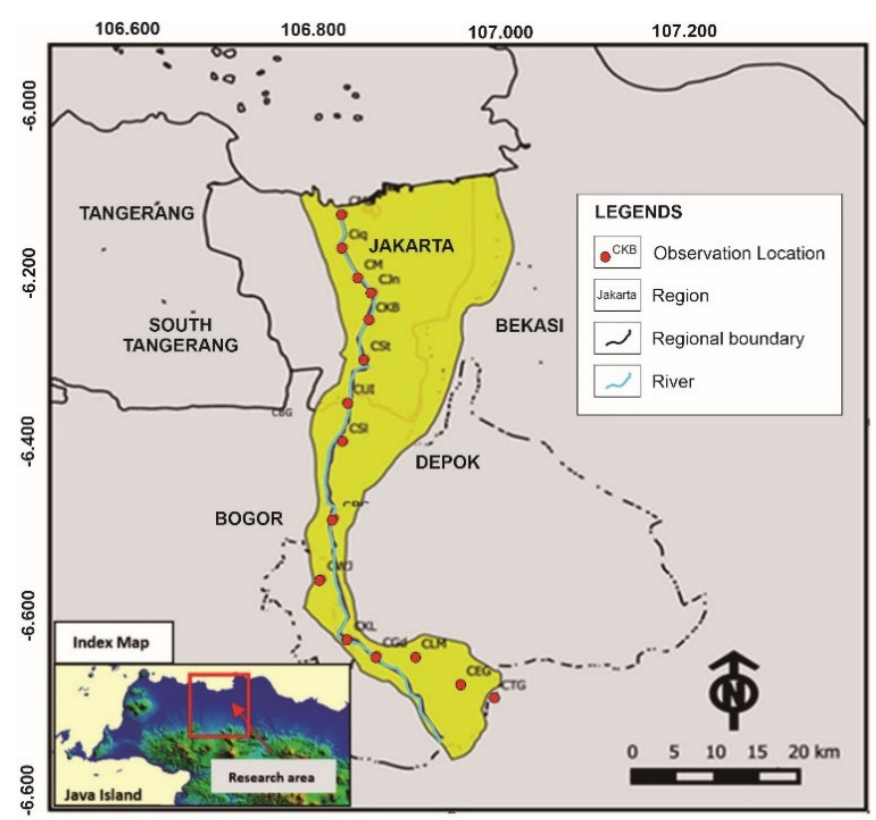

Fig 1. Observation locations of Ciliwung River 
Table 1. Observation locations for Ciliwung River and its elevations

\begin{tabular}{clcc}
\hline No & Observation location & ID & Elevation $(\mathrm{m}$ asl $)$ \\
\hline 1 & Telaga Warna & CTG & 1485 \\
2 & Evergreen & CEG & 945 \\
3 & Leuwi Malang & CLM & 637 \\
4 & Gadog & CGd & 457 \\
5 & Katulampa & CKL & 351 \\
6 & Warung Jambu & CWJ & 183 \\
7 & Bojong Gede & CBG & 116 \\
8 & Siliwangi & CSl & 72 \\
9 & Univ. Indonesia & CUI & 50 \\
10 & Simatupang & CSt & 33 \\
11 & Kalibata & CKB & 19 \\
12 & Jatinegara & CJn & 15 \\
13 & Manggarai & CM & 11 \\
14 & Istiqlal & Ciq & 7 \\
15 & Mangga Dua & CMD & 5 \\
\hline
\end{tabular}

without any special treatments. Some physical parameters such as $\mathrm{pH}$, temperature, electrical conductivity (EC) were measured directly in the fields.

\section{Materials}

IC Multi element standard VII for cations from Merck (Certipur'; HC 84849022; Na, K, Ca, M: 95$105 \mathrm{mg} / \mathrm{L}$; accuracy: 5\%) and multi anion standard 1 for IC from Sigma Aldrich (TraceCERT' ${ }^{\oplus}$ Lot: BCBSO420V; CRM: $\mathrm{Cl} 10 \mathrm{mg} / \mathrm{L}, \mathrm{SO}_{4} 20 \mathrm{mg} / \mathrm{L}$ ) were used in this investigation. Eluent solution for cation analysis was a mixture of $0.7 \mathrm{mmol} / \mathrm{L}$ of Pyridine-2,6-dicarboxylic acid (for synthesis, Merck) and $1.7 \mathrm{mmol} / \mathrm{L}$ of nitric acid $\left(\mathrm{HNO}_{3} 65 \%\right.$, Merck) whereas that for anion analysis was a mixture of $3.2 \mathrm{mmol} / \mathrm{L}$ of sodium carbonate $\left(\mathrm{Na}_{2} \mathrm{CO}_{3}\right.$, $\mathrm{M}=84.01 \mathrm{~g} / \mathrm{mol}$, Merck), $1 \mathrm{mmol} / \mathrm{L}$ of sodium hydrogen carbonate $\left(\mathrm{NaHCO}_{3}, \mathrm{M}=105.99 \mathrm{~g} / \mathrm{mol}\right.$, Merck) and $20 \mathrm{~mL}$ acetone $\left(\mathrm{CH}_{3} \mathrm{COCH}_{3}\right.$, Merck). A suppressor solution of $50 \mathrm{mmol} / \mathrm{L}$ of sulfuric acid $\left(\mathrm{H}_{2} \mathrm{SO}_{4} 95-97 \%\right.$, Merck) was needed for $\mathrm{Cl}^{-}$and $\mathrm{SO}_{4}{ }^{2-}$ analysis. Other materials were hydrochloric acid ( $\mathrm{HCl} 37 \%$, Merck), Natrium tetraborate $\left(\mathrm{Na}_{2} \mathrm{~B}_{4} \mathrm{O}_{7} \cdot 10 \mathrm{H}_{2} \mathrm{O}\right.$, Reidel-De Haen AG SeelzeHannover), pH buffer solutions of $4.01 ; 7.01 ; 10.01$ (Hanna ${ }^{\oplus}$ Instruments) and $0.45 \mu \mathrm{m}$ pore size filter paper.

\section{Instrumentation}

The equipment used in this investigation were Ion Chromatography (IC), with its specification is 833 Basic IC plus Metrohm and Compact autosampler Metrohom 863. For anion chromatography, IC is equipped by Metrosep A supp 5 (150/4) column, whereas cation chromatography is equipped by Metrosep C4 (250/4.0) column. Other equipment was Automatic Potentiometric Titrator AT-710 KEM, data logger for $\mathrm{pH}$, EC/TDS, Global Positioning System (GPS), and a set of vacuum water filtration.

\section{Procedure}

Analysis of cations and anions were conducted in the Laboratory of Hydrology - Center for Application of Isotopes and Radiation - National Nuclear Energy Agency (BATAN), which routinely participated in the proficiency test [14]. As much as $20 \mu \mathrm{L}$ of each filtered water sample was injected separately to Ion Chromatography for analysis of major cations in water samples such as $\mathrm{Na}^{+}, \mathrm{K}^{+}, \mathrm{Ca}^{2+}$, and $\mathrm{Mg}^{2+}$ as well as for analysis of anions of $\mathrm{Cl}^{-}$and $\mathrm{SO}_{4}{ }^{2-}$. Column for anions could clearly separate $\mathrm{Cl}^{-}$and $\mathrm{SO}_{4}{ }^{2-}$ from water samples in different retention time, those were approximately 6 and $15 \mathrm{~min}$, respectively. While column for cations could separate $\mathrm{Na}^{+}, \mathrm{K}^{+}, \mathrm{Ca}^{2+}$, and $\mathrm{Mg}^{2+}$ in the retention time of around $6,8,16$, and $20 \mathrm{~min}$, respectively. To make standard calibration curve, a series of standard solutions consisting of different concentrations were also injected. The curve was used to calculate back the concentration of each element in water samples. For analysis of $\mathrm{HCO}_{3}{ }^{-}$concentration in water samples, the titration method was applied using a solution of $0.02 \mathrm{~N}$ $\mathrm{HCl}$ that was previously standardized by the borax solution.

\section{- RESULTS AND DISCUSSION}

\section{Physical characteristics of Ciliwung River}

The $\mathrm{pH}$ measured in the Ciliwung River was found to be in the range of $6.63-7.71$ for the dry season and 6.56-7.86 for the rainy season. The $\mathrm{pH}$ trendline during 
the dry season, compared to the rainy season, showed more increase from the acidic $\mathrm{pH}$ at the highest upland of the Ciliwung River to the basic $\mathrm{pH}$ at the lowest land of Mangga Dua (CMD) as seen at Fig. 2. Rothwell et al. [13] explained that acidic $\mathrm{pH}$ in upland is due to vegetation covers, while in lowlands, both past and present human activities have a major impact on river water chemistry. The $\mathrm{pH}$ level at the Istiqlal Mosque site increased sporadically to 7.5 during the rainy season in 2015 that could be caused by detergent waste effluents from Cipto Mangunkusumo and Cikini Hospital at sampling time. The rising $\mathrm{pH}$ at Katulampa Dam (CKL) during periods of abundant rainfalls occurred, which could be mainly caused by the more rapid flushing or weathering carbonate minerals like calcite and dolomite consisted of limestone as materials in dam construction. Mostly, the $\mathrm{pH}$ level for Mangga Dua located nearest from the Java
Sea indicated the highest value that was probably caused by mixing between freshwater of Ciliwung River and sea water, which has $\mathrm{pH}$ value around 8.2 as measured in Ancol Beach.

Temperatures measured in the Ciliwung River were performed in Fig. 3. The temperature increased from the upstream to the downstream with the range from $21.7{ }^{\circ} \mathrm{C}$ to $30.5{ }^{\circ} \mathrm{C}$ during the rainy season and $21.3{ }^{\circ} \mathrm{C}$ to $32.5^{\circ} \mathrm{C}$ during the dry season. The highest temperature was recorded in Mangga Dua, which is measured during the dry season in 2015.

Electrical Conductivity (EC) measured in the Ciliwung River had increased from its upstream to the downstream, as seen in Fig. 4. Irawan et al. [7] found more increasing Total Dissolved Solid-TDS towards downstream, which indicated increasing enrichment and contamination. Kozaki et al. [15] investigated that EC
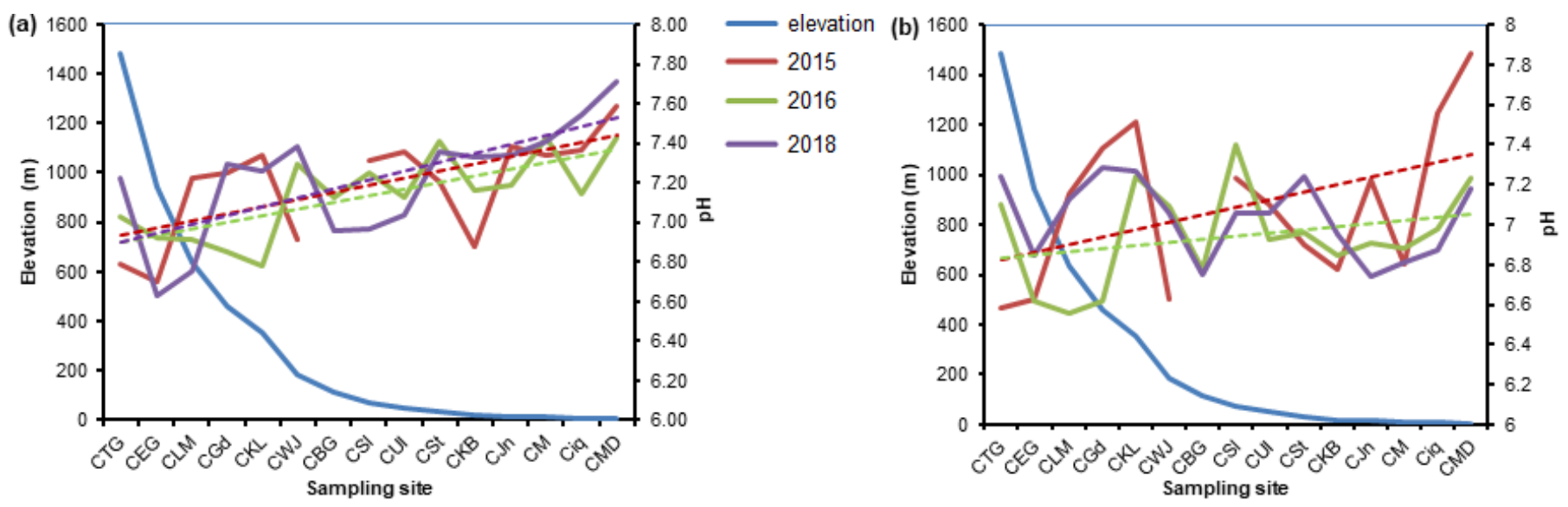

Fig 2. pH level measured in Ciliwung River in (a) the dry season and (b) the rainy season
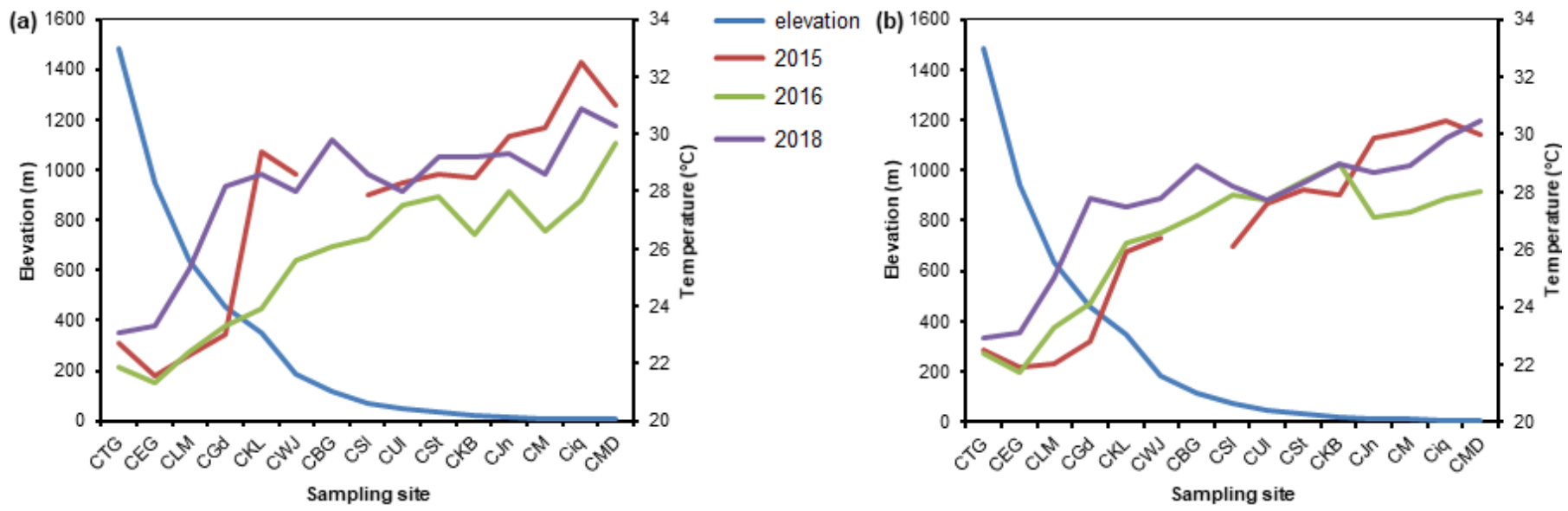

Fig 3. Temperature measured in Ciliwung River in (a) dry season and (b) the rainy season 
values increased from $150 \mu \mathrm{S} / \mathrm{cm}$ in upstream of Ciliwung River to $666 \mu \mathrm{S} / \mathrm{cm}$ in downstream. The other large variations of EC values were supposed to be mainly due to water-rock interaction along the flow paths and proximity sampling locations to the coast [16]. The EC values in Mangga Dua were more variable depending on the seasons. When water samples were measured in the dry season, EC values increased greatly more than two order magnitude compared to those measured in the rainy season as occurred in 2015 and 2018. As seen in Fig. 5, rainfall in the dry seasons, starting from May to October, in 2015 (average rainfall $=89 \mathrm{~mm}$ ) and 2018 (average rainfall $=155 \mathrm{~mm}$ ) was less than those that occurred in 2016 (average rainfall $=302 \mathrm{~mm}$ ) [17-19]. Duvert et al. [12] investigated that EC values steadily increased from Cisarua-Bogor to Jakarta during the dry season (from 450 to $890 \mu \mathrm{S} / \mathrm{cm}$ ) but was lower and less variable during the wet season (from 90 to $140 \mu \mathrm{S} / \mathrm{cm}$ ). Increasing EC values at Mangga Dua site compared to those at other sites indicated the effect of tides that enter the river, high EC values show a high salinity [20]. High evaporation in the river body in the dry season had taken a role part in the increasing EC values in most sites. Moreover, the decreasing flow rate of river water as a result of lower intensity of rainfall in the dry season could increase EC values due to the concentration of water chemistry in rivers resulted from intensive evaporation [21].

During the dry seasons, the most EC values from upper lands remained basically unchanged from CTG to CKL, except those were measured in 2016, having more constant EC values to CUI. From CWJ to CUI site, the EC values slightly increased, then elevated drastically at CSt to Ciq site for both seasons. In the later zone, the growth of population, markets, industries, and offices, as well as business centers, were fast increasing, and they produced a large volume of effluents that found their way into the Ciliwung River. For example, the wastewater effluents derived from surfactants in detergents contained the major element of $\mathrm{Na}^{+}, \mathrm{SO}_{4}{ }^{2}, \mathrm{SO}_{3}$, and $\mathrm{NH}_{4} \mathrm{OH}$, whereas those from textile processing consumed
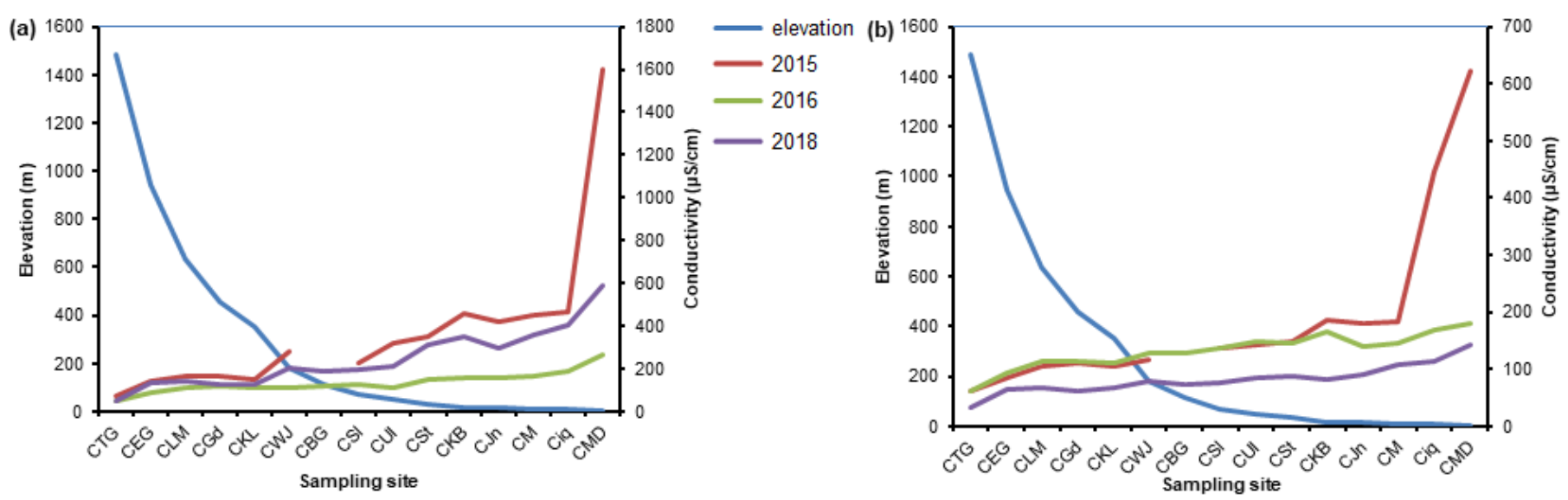

Fig 4. Electrical conductivity measured in Ciliwung River in (a) the dry season and (b) the rainy season

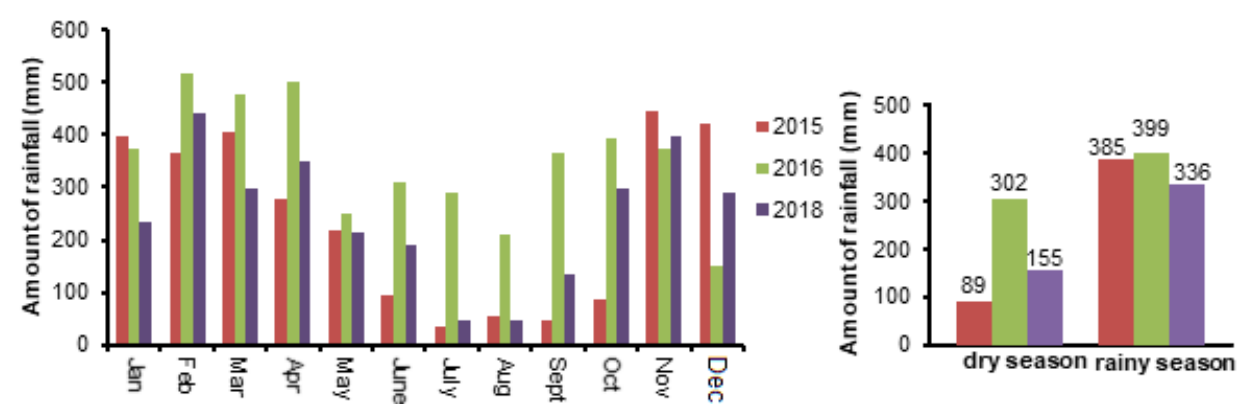

Fig 5. (a) Amount of monthly rainfalls and (b) average rainfalls in the dry and rainy season as recorded by Meteorological and Geophysical Agency in Bogor Regency [17-19] 
amount of $\mathrm{NaCl}$ and $\mathrm{KCl}$. Those dissolved salts could increase the salinity of the receiving water like a river. Degradation of organic nitrogen materials from municipal solid waste, leakage of the septic tank, and sewage sludge also produced ammonium. Under aerobic conditions, $\mathrm{NH}_{4}{ }^{+}$is oxidized by the nitrification process to nitrate. The high nitrate concentration dissolved in water was also responsible for the increasing EC value. Organic carbon materials from domestic and dead vegetation accumulated within the soil would decay by aerobic bacteria and converted it back to $\mathrm{CO}_{2}$. When waters infiltrated to the subsurface, the equilibration between water and soil $\mathrm{CO}_{2}$ occurred and produced carbonic acid as well as bicarbonate, which increased the EC value. The highest EC value in Ciliwung River was reached at the Istiqlal site in the rainy season in 2015 with its value of about $450 \mu \mathrm{S} / \mathrm{cm}$, following Mangga Dua. The rise of EC in this site could be from the accumulation of the waste effluents as additional of weathering minerals contained in the rocks.

The sporadically elevated EC value was found at CMD in both seasons, which reached $1600 \mu \mathrm{S} / \mathrm{cm}$ in the dry season in 2015 and reduced to $600 \mu \mathrm{S} / \mathrm{cm}$ in the rainy season. The decreasing EC during the dry season in 2016 and 2018 were probably caused by a higher intensity of rainfall in Bogor (as seen in Fig. 5) such that wash out and flushing of salts contained in rocks/soils were more diluted. The salinity depends on tidal height in the mouth of rivers and the discharge of freshwater in the upstream that vary on a seasonal basis. The changes in seasonal salinity patterns are also induced by mean sea level rise and freshwater flow reduction [22-23].

\section{Hydrochemical Facies of Ciliwung River}

River water evolution could be described through the piper diagram, which was plotting of concentration of major cations $\left(\mathrm{Na}^{+}, \mathrm{K}^{+}, \mathrm{Ca}^{2+}\right.$, and $\left.\mathrm{Mg}^{2+}\right)$ and anions $\left(\mathrm{Cl}^{-}, \mathrm{SO}_{4}{ }^{2-}\right.$ and $\left.\mathrm{HCO}_{3}{ }^{-}\right)$[10]. Fig. 6, 7, and 8 showed piper diagrams for all water samples collected from the Ciliwung River during the rainy and dry seasons in 2015, 2016, and 2018, respectively. Based on the dominancy of those cation and anion species, the most hydrochemical facies in the Ciliwung River were identified as (1) Ca-

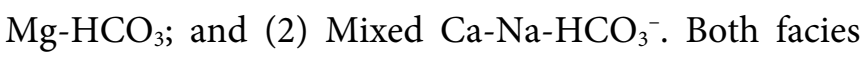
predominated, reflecting the main rock types in the Ciliwung River, where limestone [consists of calcite mineral $\left.\left(\mathrm{CaCO}_{3}\right)\right]$ and dolomites $\left[\mathrm{CaMg}\left(\mathrm{CO}_{3}\right)_{2}\right]$ were the most dominant formation.

In 2015, most samples were characterized as a mixed $\mathrm{Ca}-\mathrm{Na}-\mathrm{HCO}_{3}$ water type, except the samples from the Mangga Dua site (CMD), which had been introduced by $\mathrm{Cl}^{-}$. During the rainy season (Fig. 6(b)) the water samples tended to be more scattered as shown by Telaga Warna (CTG) and Evergreen (CEG) located in the highest upland, which belonged to $\mathrm{Ca}-\mathrm{SO}_{4}-\mathrm{HCO}_{3}$ water type. During the dry season in the year of 2015, CTG belonged to $\mathrm{Ca}-\mathrm{HCO}_{3}$ water type while $\mathrm{CEG}, \mathrm{CGd}$, and CLM sites had shifted to $\mathrm{Ca}-\mathrm{Mg}-\mathrm{Na}-\mathrm{HCO}_{3}$. In the

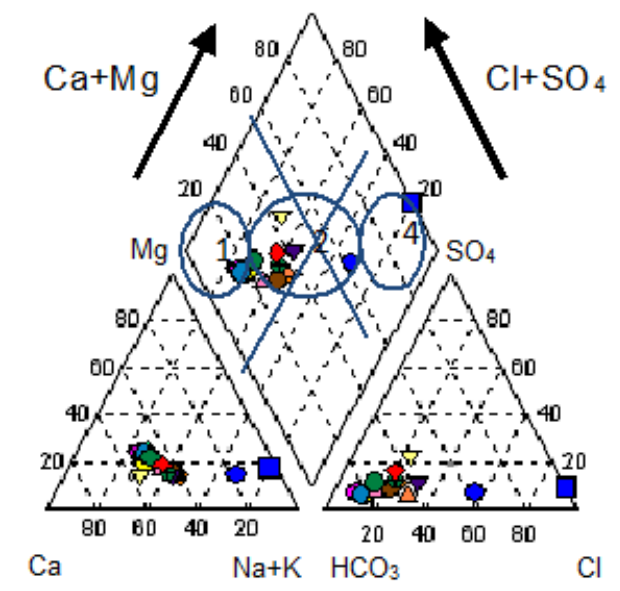

(a)

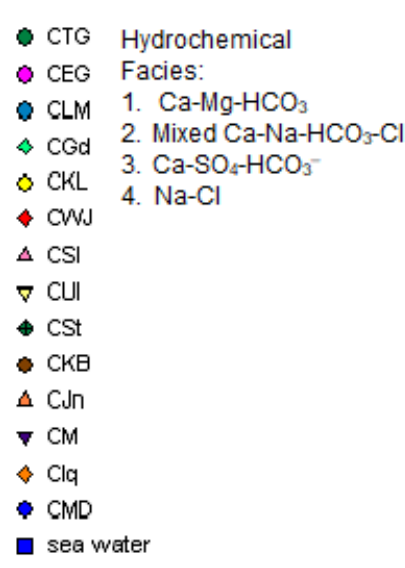

$\mathrm{Ca}$

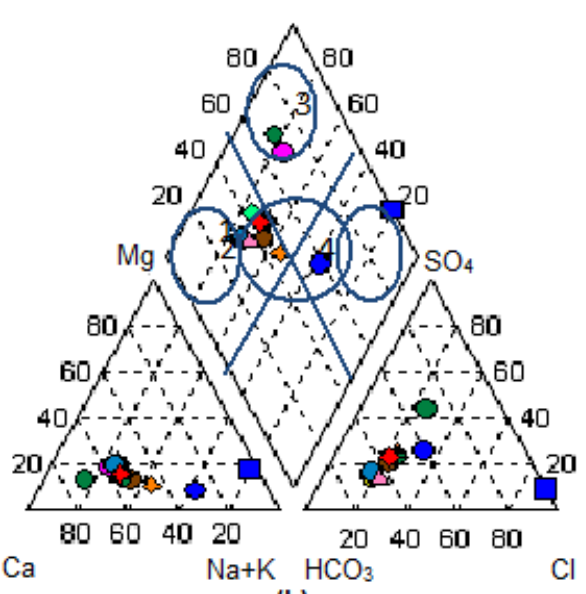

(b)

Fig 6. Water type of the Ciliwung River collected in (a) the dry season and (b) the rainy season 2015 
next sites, Ca-Na- $\mathrm{HCO}_{3}$ water type predominated Ciliwung River water until CIq, which belonged to $\mathrm{Ca}-$ $\mathrm{Na}-\mathrm{HCO}_{3}-\mathrm{Cl}$ and finally predominated by $\mathrm{Na}-\mathrm{Cl}-\mathrm{HCO}_{3}$ in CMD as seen at Fig. 6(a). The point of Mangga Dua (CMD) that rather lied in the right side of the diamond shape in the piper diagram showed a tendency to $\mathrm{Na}-\mathrm{Cl}$ water type as a characteristic of sea water due to the proximity of Mangga Dua site to Jakarta Bay. The salinization path due to sea water admixture toward CMD site also occurred in the rainy season 2015, which was predominated by $\mathrm{Na}-\mathrm{Ca}-\mathrm{HCO}_{3}-\mathrm{Cl}$.

In the case of water samples collected in the year 2016 and 2018, as described in Fig. 7 and Fig. 8, respectively, seemly $\mathrm{Ca}-\mathrm{Na}-\mathrm{HCO}_{3}$ facies still predominated for all water samples in both seasons, including the Mangga Dua site. However, during the dry season, this site (CMD) slightly moved to $\mathrm{Ca}-\mathrm{Na}-\mathrm{HCO}_{3}-$ $\mathrm{Cl}$ facies, reflecting a few encroachments of chloride from sea water than that occurred in 2015. A higher amount of monthly rainfall (average $=302 \mathrm{~mm}$ ) during the dry season in 2016 might have influenced to more rapid flushing of freshwater instead of sea water flush.

To have a more clear understanding of water chemistry evolutions, a Schoeller diagram for cation and anion concentrations for each water sample in the logarithmic scale was made. Those were described in

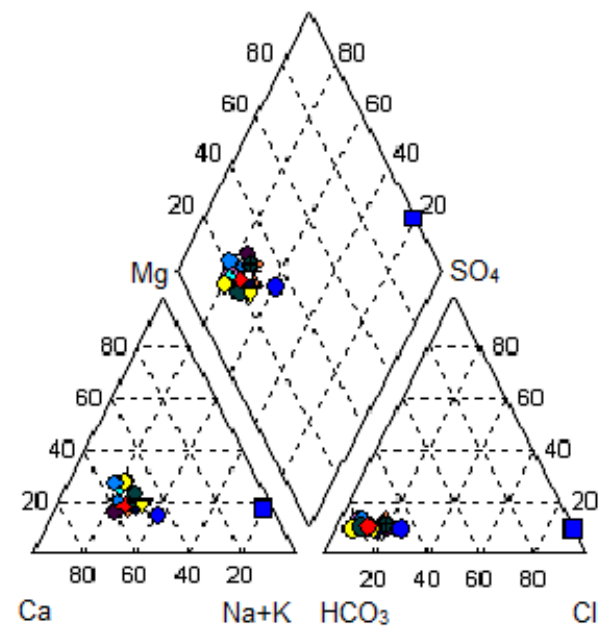

(a)

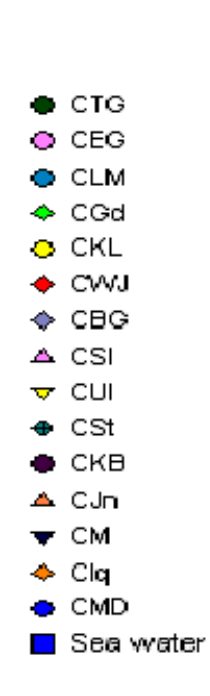

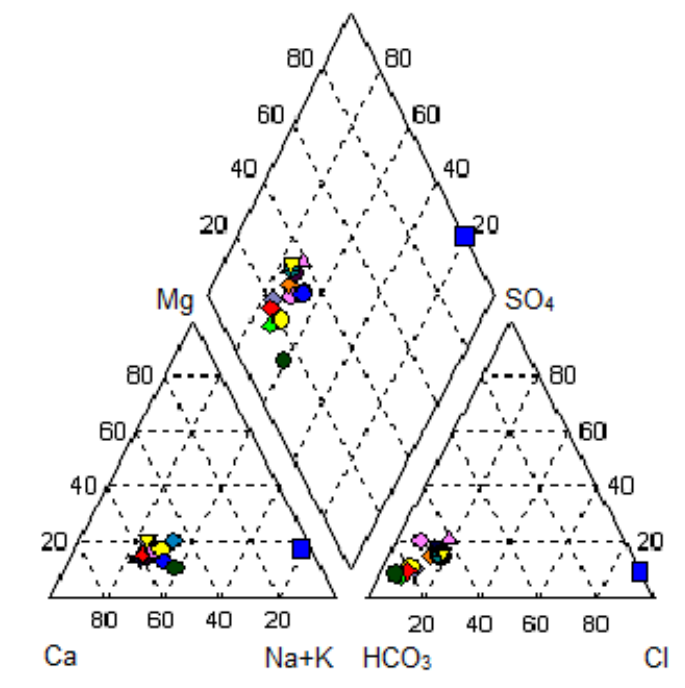

(b)

Fig 7. Water type of the Ciliwung River collected in (a) the dry season and (b) the rainy season 2016

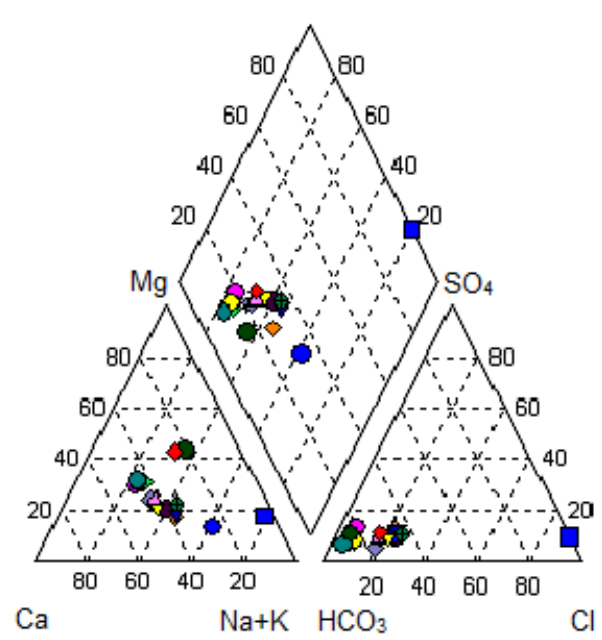

(a)

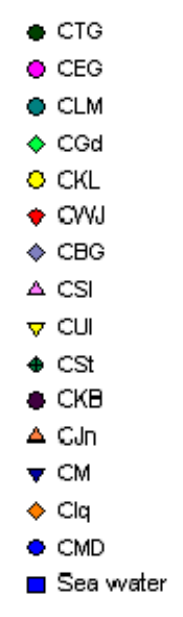

Sea water

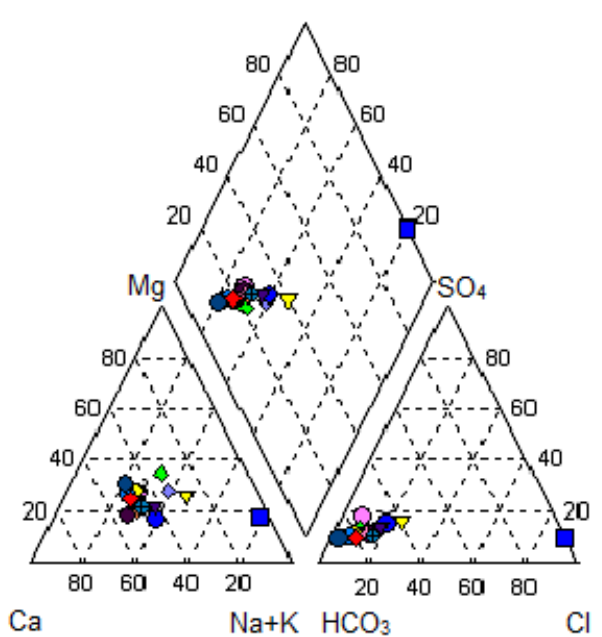

(b)

Fig 8. Water type of the Ciliwung River collected in (a) the dry season and (b) the rainy season 2018 
Fig. 9, 10, and 11 for collecting samples in 2015, 2016, and 2018, respectively. During the dry season in 2015, all anion and cation concentrations tended to be higher than those in the rainy season. The presence of a high concentration of $\mathrm{Mg}^{2+}, \mathrm{Ca}^{2+}, \mathrm{Na}^{+}, \mathrm{Cl}^{-}, \mathrm{SO}_{4}{ }^{2-}$, in a coastal area, as shown in the Mangga Dua site, could be due to flushing of sea water which apparently increased during dry season 2015. However, that sporadic increasing trend of chemical concentration in the Mangga Dua site was not found during collecting samples in 2016 and 2018 in which the chemical concentrations were more constant in both seasons. The more rapid flushing of river water resulted from higher monthly rainfall during both seasons in 2016 and 2018 (as seen in Fig. 5) could be the reason for more constant chemical concentration at Mangga Dua site.

With the exception of CMD sites, generally, the major cations in Ciliwung river observed in 2015, 2016 and 2018 could be ranked in term of proportion (unit of meq/L) as follows: $\mathrm{Ca}^{2+}>\mathrm{Na}^{+}>\mathrm{Mg}^{2+}>\mathrm{K}^{+}$and the major anions as $\mathrm{HCO}_{3}{ }^{-}>\mathrm{Cl}^{-}>\mathrm{SO}_{4}{ }^{2}$. On the other hand, the CMD site observed during both seasons in 2015 showed the following rank: $\mathrm{Na}>\mathrm{Ca}>\mathrm{Mg}>\mathrm{K}$ for cations and $\mathrm{Cl}>\mathrm{HCO}_{3}>\mathrm{SO}_{4}$ for anions. Those concentrations decreased significantly in flood season because of the increasing dilution effect.

In the highest elevation (1485 m) of Ciliwung River, most anion and cation compositions were distributed at the lowest concentration. Seemly, the higher monthly rainfall occurred during dry seasons in 2016 and 2018, as seen in Fig. 5(b) did not significantly influence hydrochemical compositions at the Telaga Warna site. A similar case also occurred during the dry season in 2015, even though its monthly rainfall was categorized as below normal condition [17]. In that season, $\mathrm{Ca}^{2+}(6 \mathrm{ppm})$ and

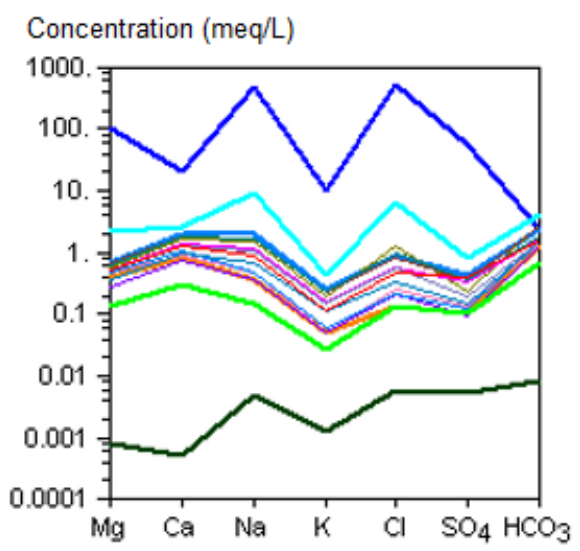

(a)

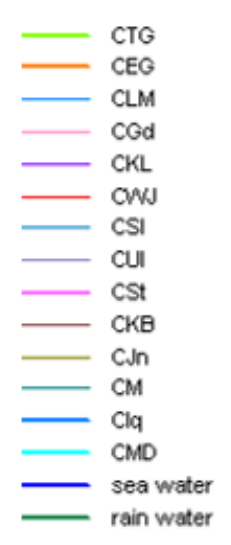

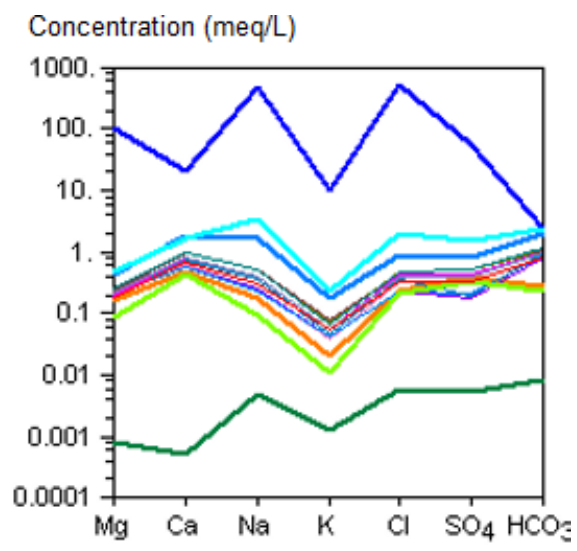

(b)

Fig 9. Chemical compositions for Ciliwung River in (a) the dry season and (b) the rainy season 2015

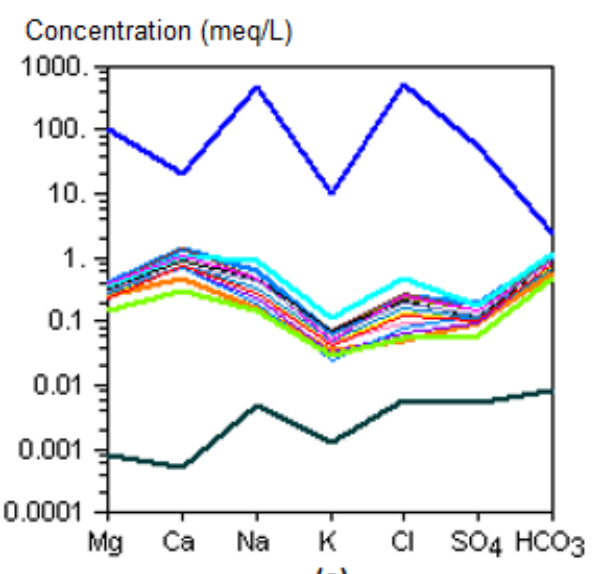

(a)

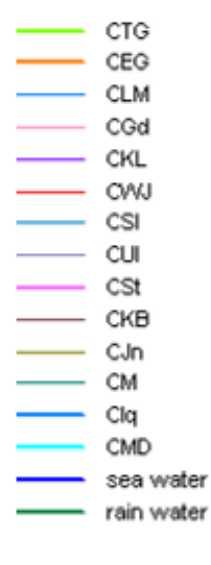

西

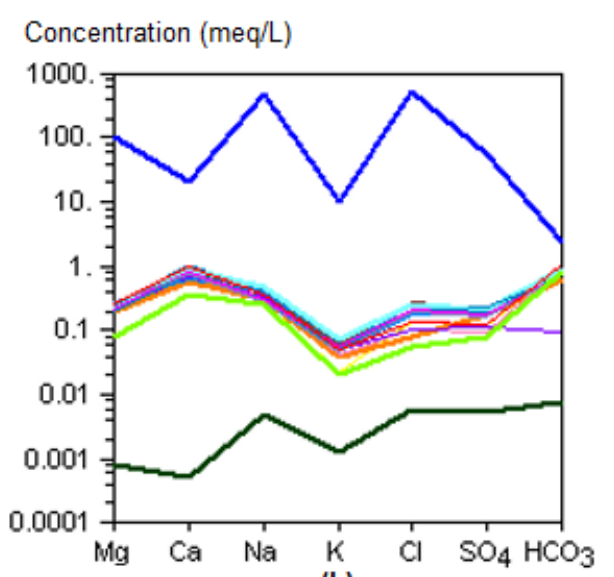

(b)

Fig 10. Chemical compositions for Ciliwung River in (a) the dry season and (b) the rainy season 2016 


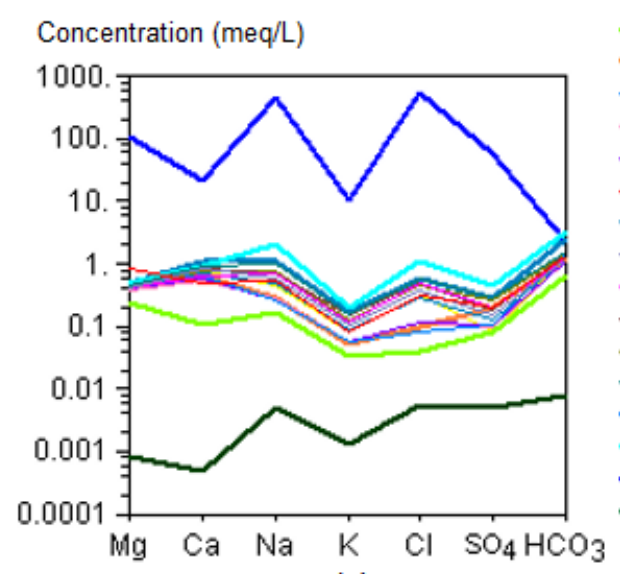

(a)

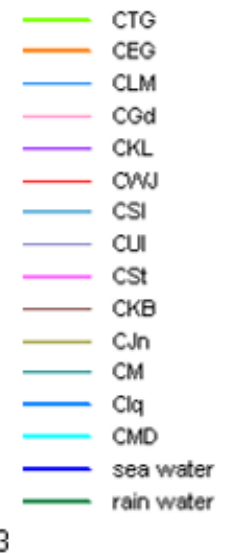

.

Fig 11. Chemical compositions for Ciliwung River in (a) the dry season and (b) the rainy season 2018

$\mathrm{HCO}_{3}^{-}$(43 ppm) were the dominant constituents in Telaga Warna Lake, followed by $\mathrm{Na}^{+}(4 \mathrm{ppm})$ and $\mathrm{Mg}^{2+}(2$ ppm) for cations, as well as $\mathrm{SO}_{4}{ }^{2-}(5 \mathrm{ppm})$ and $\mathrm{Cl}^{-}(4 \mathrm{ppm})$ for anions. Those concentrations increased along the flow path until to the mouth of Jakarta Bay, indicating that the dissolution of minerals had been still in progress.

The mineral dissolution process, together with river water evaporation during the dry season, could result in the extent of increasing anion and cation concentrations. Those constituents reached maximum concentration in the endpoint of the Ciliwung River flow at Mangga Dua. However, those orders clearly changed in which $\mathrm{Na}^{+}$as the dominant constituent (213 ppm) in coastal site replaced calcium (51 ppm) as the main constituent of the Ciliwung River in the highest upland. Besides mineral dissolution and evaporation, the common pathways of salinization into the freshwater system are mixing with sea water and cation exchange process in most coastal regions. However, chemical reactions like the cation exchange process effect little to the concentration of water chemistry compared to sea water mixing $[8,16]$.

\section{Mixing of Freshwater with Sea Water}

Based on a mass balance model, mixing lines between two different water samples for a range of hydrochemical indicators can be calculated using a simple mixing equation through AQUACHEM program as follow: $\mathrm{C}_{\text {mix }}=\mathrm{C}_{1} \mathrm{n}+\mathrm{C}_{2}(1-\mathrm{n})$, where $\mathrm{C}_{\text {mix }}$ is the ion concentration of mixture sample, $\mathrm{C}_{1}$ is ion concentration of sea water, and $\mathrm{C}_{2}$ is ion concentration of rainwater.

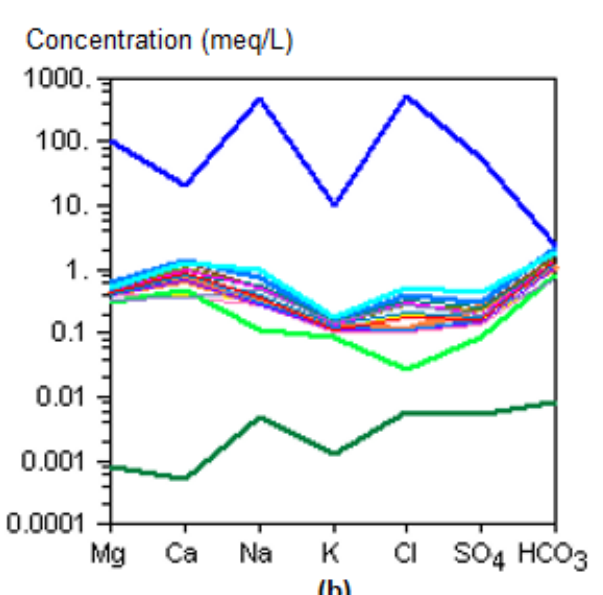

(b)
Notation $\mathrm{n}$ represents a mixing fraction of sea water in river water, whereas $1-n$ is the fraction of rainwater $[8,24]$. Hence, increasing of $\mathrm{Cl}^{-}$and $\mathrm{Na}^{+}$concentration for each step of mixing fraction could be calculated by the equation, and then the calculated admixtures were plotted in $\mathrm{Na}^{+}$versus $\mathrm{Cl}^{-}$graph.

Fig. 12 showed that during the rainy season in 2015, the river water in Mangga Dua might be estimated as much as $0.7 \%$ of sea water composition. The less mixing fraction of sea water, about $0.3 \%$, was signified at the Istiqlal site. When the river water was taken during the dry season, the mixing fraction of sea water in the Mangga Dua site increased to approximately $2 \%$. The other sites starting from CWJ to Ciq showed a shifting of $\mathrm{Na}^{+}$and $\mathrm{Cl}^{-}$concentrations to the higher mixing fraction of saline water. The increasing of $\mathrm{Na}^{+}$and $\mathrm{Cl}^{-}$in this zone was compared well with the elevating of the EC values (see Fig. 4) that could be derived from past or present domestic or industrial waste. However, it was also considered that huge evaporation during water flow due to the hot landscape in the dry season became a dominant effect on the samples, which located far away from the shoreline.

During the dry season 2016 (Fig. 13), the mixing fraction of sea water into CMD site decreased to less than $0.2 \%$ that was still higher than that was taken in the rainy season. Rather similar evidence also occurred in dry season 2018 (Fig. 14) that had a mixing fraction of sea water as much as $0.4 \%$. Their $\mathrm{Na}-\mathrm{Cl}$ compositions were in the same clusters as other sites. For three year 


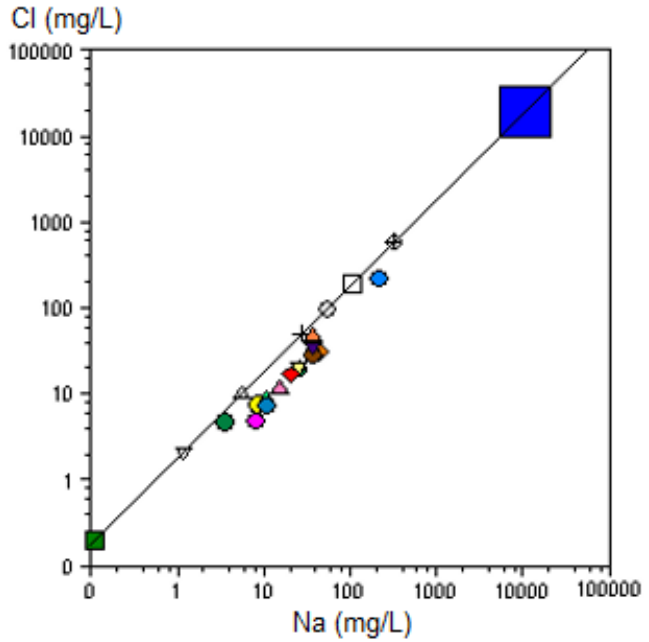

(a)

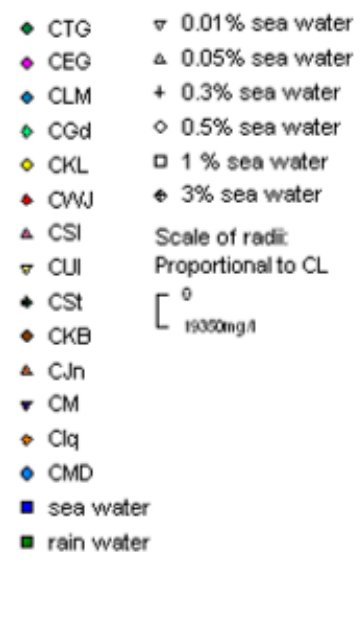

- CEO

- CLM

- CGd

CSI

CIn

- sea water

rain water

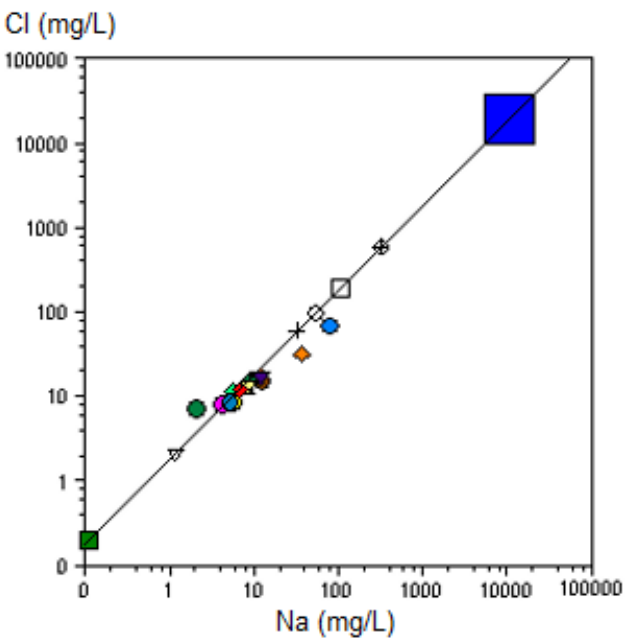

(b)

Fig 12. Mixing fraction of sea water into the river in (a) the dry season and (b) the rainy season 2015

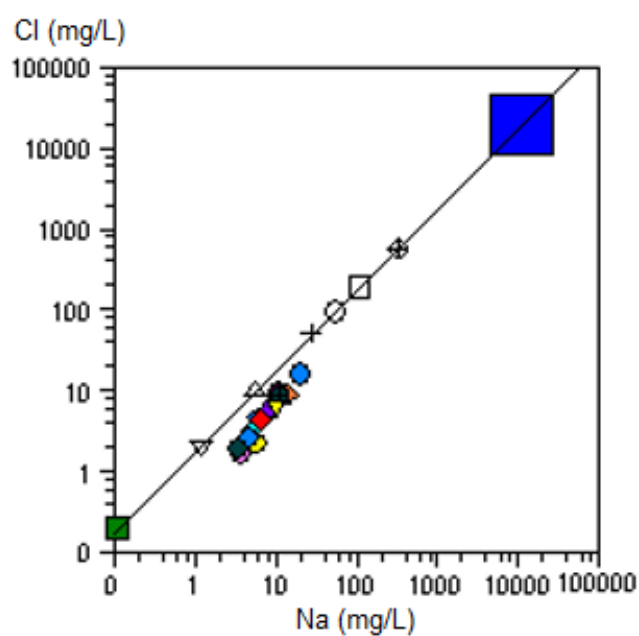

(a)

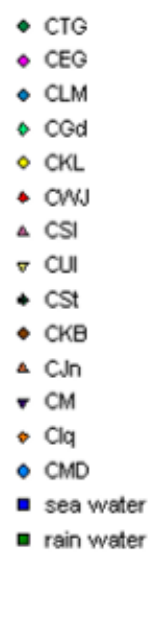

- $0.01 \%$ sea water

$\triangle 0.05 \%$ sea water

$+0.3 \%$ sea water

$0.5 \%$ sea water

- $1 \%$ sea water

- $3 \%$ sea water

Scale of radif

Proportional to CL

${ }^{0}$ naskingn

sea water

rain water

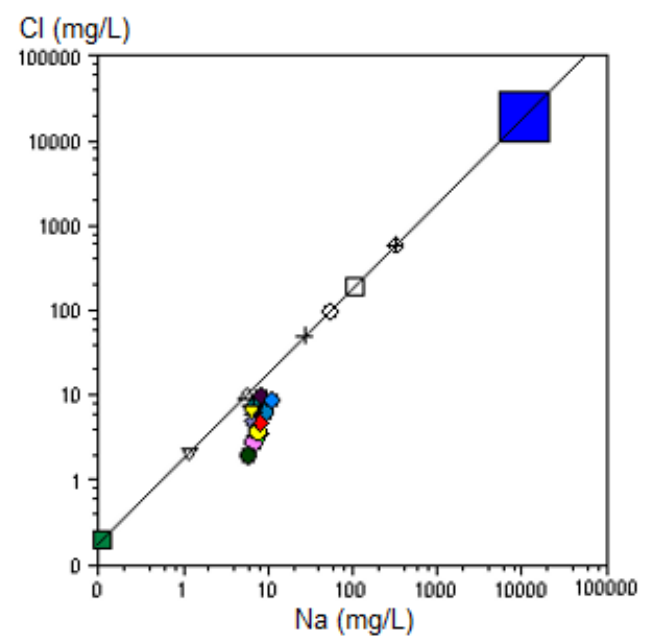

(b)

Fig 13. Mixing fraction of sea water into the river in (a) the dry season and (b) the rainy season 2016

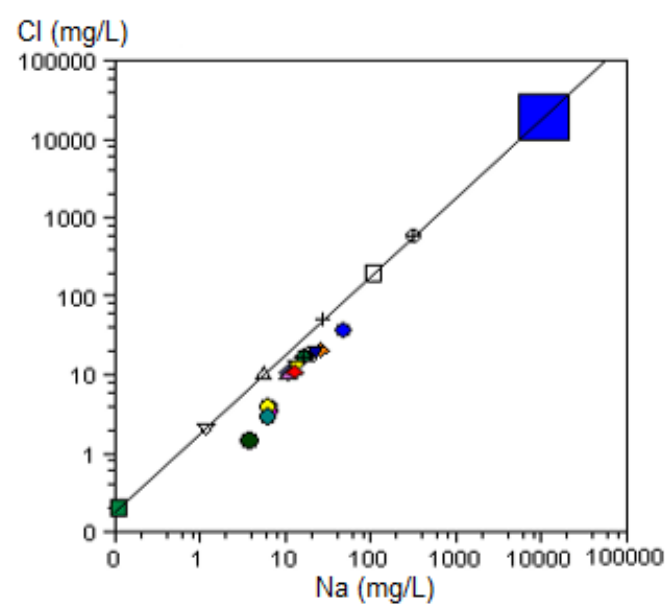

(a)

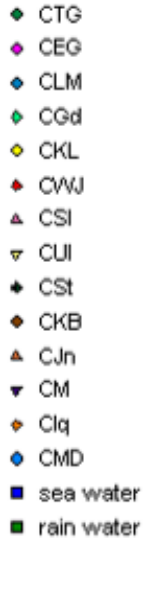

- CEG

- çd

$\circ \mathrm{CKL}$

- CNS

$\rightarrow$ CUI

+ CSt

- CKB

- $\mathrm{CM}$

- Cla

- sea water

$\rightarrow 0.01 \%$ sea water

$\triangle 0.05 \%$ sea water

$+0.3 \%$ sea water

- $0.5 \%$ sea water

व $1 \%$ sea water

- $3 \%$ sea water

Scale of radii:

Proportional to $\mathrm{CL}$

$\left[\begin{array}{l}0 \\ 19350 \mathrm{ng} / 1\end{array}\right.$

Fig 14. Mixing fraction of sea water into the river in (a) the dry season and (b) the rainy season 2018

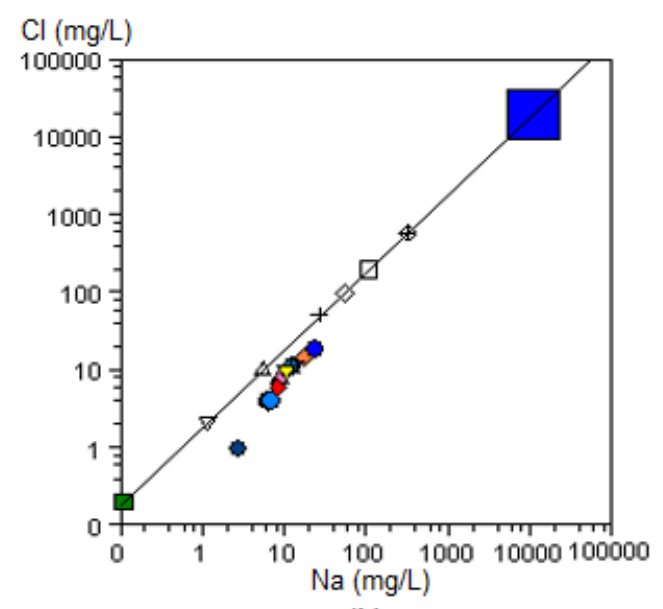

(b) 
investigations, the mixing fraction of sea water to the river located nearest to shoreline increased during the dry season. The important mechanisms forcing for flow and salt transport in the nearshore region are driven by tides, waves, their interaction with beach morphology and seasonal changes in the inland water table elevations [25].

\section{Saturation Index (SI)}

As mentioned above, most samples from the Ciliwung River were dominated by bicarbonate for anion showing interaction with carbonate rocks. Dissolving calcite $\left(\mathrm{CaCO}_{3}\right)$ and dolomite $\left[\mathrm{CaMg}\left(\mathrm{CO}_{3}\right)_{2}\right]$ contained in carbonate rocks follows to these reactions [16]:

$\mathrm{CaCO}_{3}+\mathrm{CO}_{2}+\mathrm{H}_{2} \mathrm{O} \rightleftarrows \mathrm{Ca}^{2+}+\mathrm{HCO}_{3}^{-}$

$\mathrm{CaMg}\left(\mathrm{CO}_{3}\right)_{2}+2 \mathrm{CO}_{2}+2 \mathrm{H}_{2} \mathrm{O} \rightleftarrows \mathrm{Ca}^{2+}+\mathrm{Mg}^{2+}+4 \mathrm{HCO}_{3}{ }^{-}$

Whereas for evaporating rocks of gypsum minerals $\left(\mathrm{CaSO}_{4} 2 \mathrm{H}_{2} \mathrm{O}\right)$ follows the reaction [8]:

$\mathrm{CaSO}_{4}+2 \mathrm{H}_{2} \mathrm{O} \rightleftarrows \mathrm{Ca}^{2+}+\mathrm{SO}_{4}{ }^{2-}+2 \mathrm{H}_{2} \mathrm{O}$

To evaluate the degree of equilibrium between water and minerals, the used parameter is the saturation index
(SI), which was calculated using PHREEQC software. Changes in saturation state are useful to distinguish different stages of hydrochemical evolution and to identify which geochemical reaction is important in controlling water chemistry. The saturation index of minerals is obtained from the equation of $\mathrm{SI}=\log$ (IAP/Kt). The term of IAP is the Ion Activity Product of the dissociated chemical species in solution. $\mathrm{Kt}$ is the equilibrium solubility product for the chemical involved at the sample temperature [16,26-27].

Fig. 15, 16, and 17 showed the SI for calcite, dolomite, and gypsum against the order of sampling locations of the Ciliwung River for sampling periods of 2015, 2016, and 2018, respectively. Along with river flow, SI with respect to calcite mineral was the highest value, among other minerals. All water samples had negative SI values in 2016 (Fig. 16) and during the rainy season 2018 (Fig. 17(b)). It suggested that all water samples were undersaturated with respect to calcite, dolomite, and gypsum minerals. Such an undersaturated
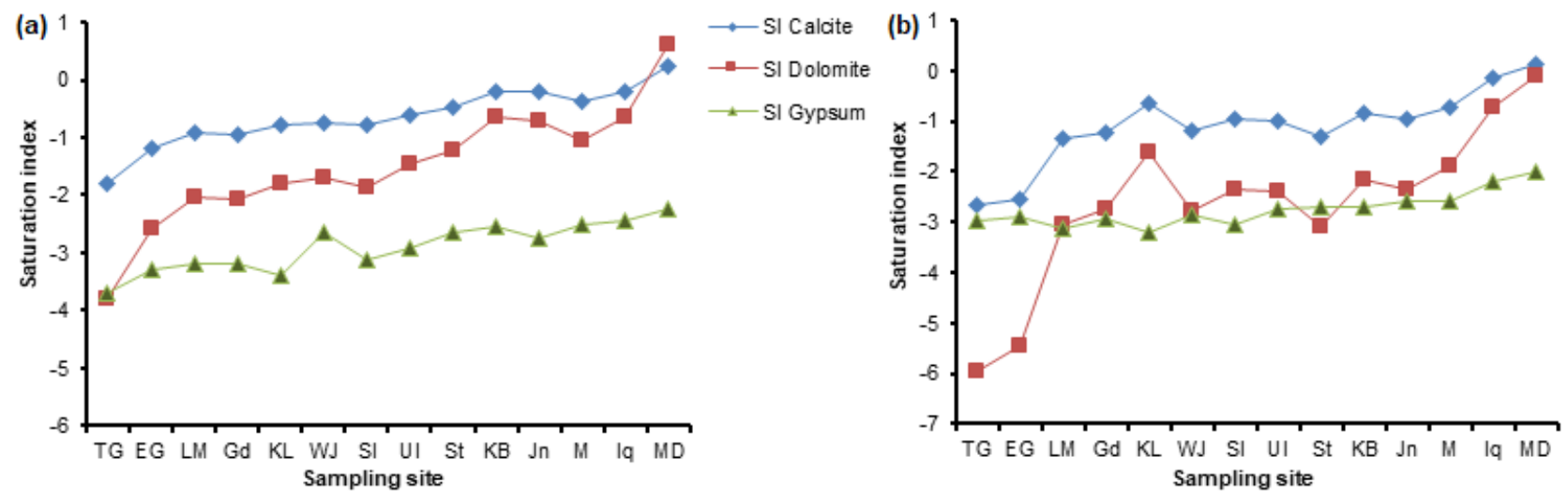

Fig 15. Saturation indexes for some minerals in (a) the dry season and (b) the rainy season 2015
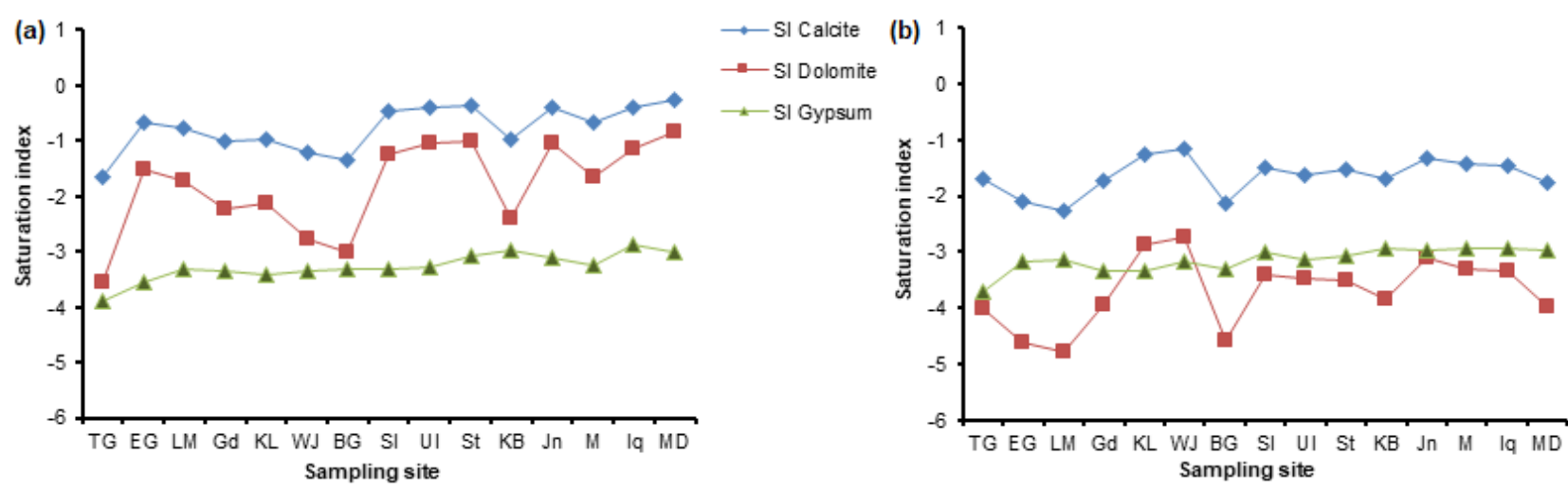

Fig 16. Saturation indexes for some minerals in (a) the dry season and (b) the rainy season 2016 

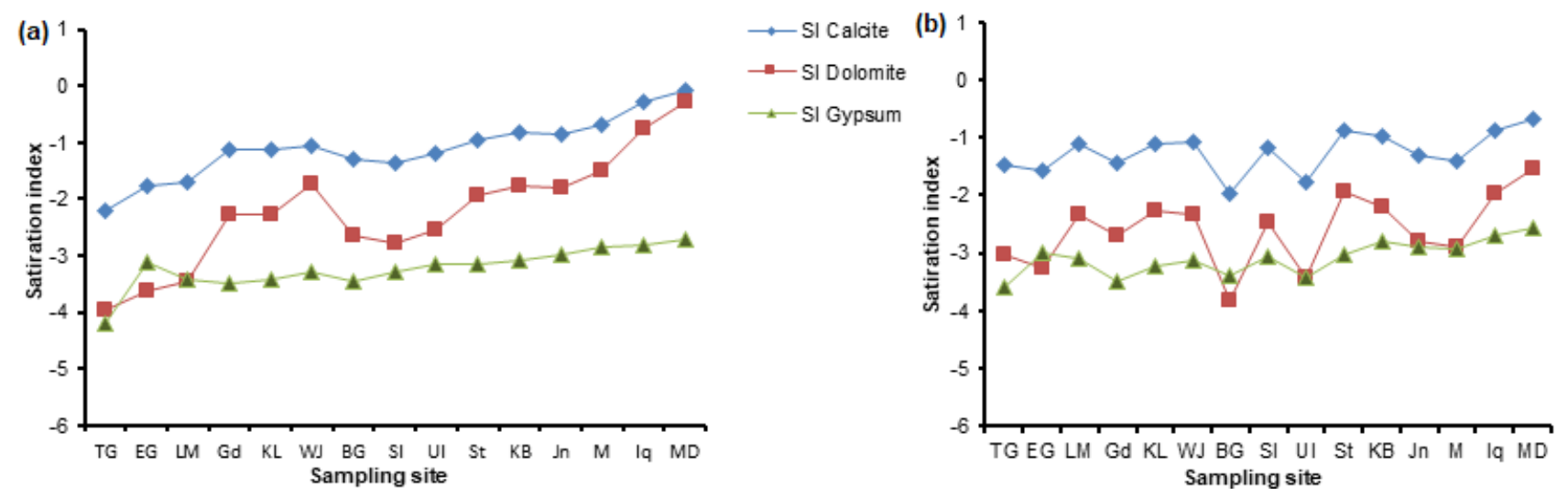

Fig 17. Saturation indexes for some minerals in (a) the dry season and (b) the rainy season 2018

term reflects the character of water with insufficient amount of calcite, dolomite, and gypsum mineral for solution.

Bicarbonate as a dominant anion might have been influenced by the dissolution of calcite and dolomite mineral phases. However, the higher SI for calcite than SI for dolomite showed that more amount of $\mathrm{HCO}_{3}{ }^{-}$ concentration in the system was dominantly influenced by calcite dissolution. The higher dissolution for calcite was shown from saturated condition $(\mathrm{SI}=0)$ in the Istiqlal site while SI with respect to dolomite still remained at undersaturated $(\mathrm{SI}<0)$ as taken place in 2015 . The saturated condition means that the water samples are in equilibrium with respect to the particular minerals [16,27]. Besides dissolved $\mathrm{HCO}_{3}{ }^{-}$, calcite also could dissolve in the system by adding $\mathrm{Ca}^{2+}$, whereas dolomite dissolved its $\mathrm{Mg}^{2+}$ concentration to the solution. All water samples were undersaturated with respect to gypsum indicated that gypsum also could dissolve in the system by adding $\mathrm{Ca}^{2+}$ and $\mathrm{SO}_{4}{ }^{2-}$ to the solution. The much less gypsum SI compared to calcite SI in all water samples implied that $\mathrm{Ca}^{2+}$ in the solution might be highly contributed from the dissolution of calcite rather than the dissolution of gypsum minerals.

In 2015, the SI of calcite, dolomite, and gypsum steadily increased related to the decreasing elevation of sampling sites. It meant that the water samples contained more amounts of ion concentrations with more sufficient residence time of water in which was controlled by volume and mechanism of mineral dissolution. In the Mangga Dua site, SI of calcite reached to supersaturated
(SI $>1$ ) in both seasons, while SI of dolomite reached to supersaturated in the dry season. A supersaturated condition means that the water sample is incapable of dissolving more of the mineral $[16,27]$. It implied that both minerals had a great dissolution and strong mineralization that potentially lead to precipitation. The strong mineralization in Mangga Dua could be due to the large influence of minerals from sea water, in addition to the mineral dissolution along with the river flow. The SI for CMD site during the dry season in 2018 reflected a saturated condition with respect to calcite and closed to saturated $(\mathrm{SI}=-0.22)$ with respect to dolomite.

\section{- CONCLUSION}

Electrical conductivity (EC), temperature, and $\mathrm{pH}$, which were measured along the Ciliwung River, generally increased with the decreasing elevation lands. The much more amount of rainfall as occurred in 2016 and 2018 than that in 2015 could result in a decrease of EC values in a site near the coast. With the exception of Mangga Dua site, cation concentrations could be ranked as $\mathrm{Ca}^{2+}>\mathrm{Na}^{+}>\mathrm{Mg}^{2+}>\mathrm{K}^{+}$and for anion concentration as $\mathrm{HCO}_{3}{ }^{-}>\mathrm{Cl}^{-}>\mathrm{SO}_{4}{ }^{2-}$. In general, the hydrochemical facies that could be identified for the Ciliwung River were $\mathrm{Ca}-\mathrm{Mg}-\mathrm{HCO}_{3}$ and $\mathrm{Ca}-\mathrm{Na}-\mathrm{HCO}_{3}$. In 2015, the introduction of salinity into the river had reached to Mangga Dua shifting its water type to $\mathrm{Na}-\mathrm{Ca}-\mathrm{HCO}_{3}-\mathrm{Cl}$. The fraction of sea water into Ciliwung River was optimized as much as $2 \%$ in the Mangga Dua site during the dry season and decreased to approximately $0.7 \%$ during the rainy season. Calculated saturation indexes 
with respect to calcite, dolomite, and gypsum minerals showed an increasing trend related to the decreasing elevation land. Mostly, the Ciliwung River water was undersaturated with respect to these minerals, indicating the insufficient amount of these minerals for dissolution. However, the calcite and dolomite saturation indexes in the Mangga Dua site had nearly reached saturated conditions (during the rainy season in 2015 and dry season 2018) and to supersaturated (during the dry season in 2015) representing for a great dissolution and strong mineralization.

\section{- ACKNOWLEDGMENTS}

This study was funded by the Government of Indonesia through the 2015-2019 National Mid-term Development Plan. The sincere thanks were extended to all staff in Hydrology Laboratory - Center for Isotope and Radiation Applications for their assistances during collecting and analyzing samples.

\section{- REFERENCES}

[1] Hendrayanto, 2008, Transboundary watershed management: A case study of upstream-downstream relationships in Ciliwung watershed, Bull. TERC, Univ. Tsukuba, 8 (2), 8-11.

[2] Pramono, I.B., 2016, Distribution of water infiltration rate in Ciliwung Watershed, Forum Geografi, 30 (1), 24-33.

[3] Mukhaiyar, R., 2017, Digital image and remote sensing image as a data for an identification of a quality of a non-point source pollutant in Ciliwung River-Indonesia, Int. J. GEOMATE, 12 (32), 142-151.

[4] Ohte, N., Watanabe, Y., Yoshimizu, C., Kondo, A., Runtunuwu, E., Yamanaka, T., and Tanaka, T., 2010, Stable isotope of nitrate in Ciliwung River, Bull. TERC, Univ. Tsukuba, 10 (Suppl. 1), 65-74.

[5] Delinom, R.M., 2010, Geology and hydrogeology of Ciliwung, Bull. TERC, Univ. Tsukuba, 10 (Suppl. 1), 27-33.

[6] Sulistyowati, R., Hapsari, R.I., Syamsudin, F., Mori, S, Oishi, S.T., and Yamanaka, M.D., 2014, Rainfalldriven diurnal variations of water level in the Ciliwung River West Jawa-Indonesia, SOLA, 10, 141-144.
[7] Irawan, D.E., Silaen, H., Sumintadireja, P., Lubis, R.F., Brahmantyo, B., and Puradimeja, D.J., 2015, Groundwater-surface water interactions of Ciliwung River streams, segment Bogor-Jakarta, Indonesia, Environ. Earth Sci., 73 (3), 1295-1302.

[8] Hui, Q., Peiyue, L., Jia, D., Chao,Y., and Xuedi, Z., 2011, Formation of the river water chemistry in the middle section of Dousitu River-China, E-J. Chem., 8 (2), 727-738.

[9] Birks, S.J., Moncur, M.C., Gibson, J.J., Yi, Y., Fennell, J.W., and Taylor, E.B., 2018, Origin and hydrogeological setting of saline groundwater discharges to the Athabasca River: Geochemical and isotopic characterization of the hyporheic zone, Appl. Geochem., 98, 172-190.

[10] Jiang, L., Yao, Z., Liu, Z., Wang, R., and Wu, S., 2015, Hydrochemistry and its controlling factors of rivers in the source region of the Yangtze River on the Tibetan Plateau, J. Geochem. Explor., 155, 76-83.

[11] Lindell, L., Åström, M., and Öberg, T., 2010, Landuse change versus natural controls on stream water chemistry in the Subandean Amazon, Peru, Appl. Geochem., 25 (3), 485-495.

[12] Duvert, C., Priadi, C.R., Rose, A.M., Abdillah, A., Marthanty, D.R., Gibb, K.S., and Kaestli, M., 2019, Sources and drivers of contamination along an urban tropical river (Ciliwung, Indonesia): Insights from microbial DNA, isotopes and water chemistry, Sci. Total Environ., 682, 382-393.

[13] Rothwell, J.J., Dise, N.B., Taylor, K.G., Allott, T.E.H., Scholefield, P., Davies, H., and Neal, C., 2010, Spatial and seasonal assessment of river water chemistry across North West England, Sci. Total Environ., 408 (4), 841-855.

[14] Wassenaar, L.I., Terzer-Wassmuth, S., Douence, C., Araguas-Araguas, L., Aggarwal, P.K., and Coplen, T.B., 2018, Seeking excellence: An evaluation of 235 international laboratories conducting water isotope-ratio and laser absorption spectrometry, Rapid Commun. Mass Spectrom., 32 (5), 393-406.

[15] Kozaki, D., Ozaki, T., Nakatani, N., Mori, M., and Tanaka, K., 2014, Utilization of ion-exclusion chromatography for water quality monitoring in 
suburban river in Jakarta, Indonesia, Water, 6 (7), 1945-1960.

[16] Sappa, G., Barbieri, M., Ergul, S., and Ferranti, F., 2012, Hydrogeological conceptual model of groundwater from carbonate aquifers using environmental isotopes $\left({ }^{18} \mathrm{O},{ }^{2} \mathrm{H}\right)$ and chemical tracers: A case study in Southern Latium RegionCentral Italy, J. Water Resour. Prot., 4, 695-796.

[17] Central Bureau of Statistics in Bogor Regency, 2016, Bogor Regency in Figures, BPS-Statistics of Bogor Regency, BPS Catalog: 1102001.3201.

[18] Central Bureau of Statistics in Bogor Regency, 2017, Bogor Regency in Figures, BPS-Statistics of Bogor Regency, BPS Catalog: 1102001.3201.

[19] Central Bureau of Statistics in Bogor Regency, 2019, Bogor Regency in Figures, BPS-Statistics of Bogor Regency, BPS Catalog: 1102001.3201.

[20] Purnaini, R., Sudarmadji., and Purwono, S., 2018, Tidal influence on water quality of Kapuas Kecil river downstream, E3S Web Conf., 31, 04006.

[21] Edokpayi, J.N., Odiyo, J.O., Popoola, E.O., and Msagati, T.A.M., 2017, Evaluation of temporary seasonal variation of heavy metals and their potential ecological risk in Nzhelele River-South Africa, Open Chem., 15 (1), 272-282.

[22] Vargas, C.I.C., Vaz, N., and Dias, J.M., 2017, An evaluation of climate change effect in estuarine salinity patterns: Application to Ria de Aveiro shallow water system, Estuarine, Estuarine Coastal Shelf Sci., 189, 33-45.

[23] Anderson, C.J., and Lockaby, B.G., 2012, Seasonal patterns of river connectivity and saltwater intrusion in tidal freshwater forested wetlands, River Res. Appl., 28 (7), 814-626.

[24] Han, D.M., Song, X.F., Currel, M.J., Yang, J.L., and Xiao, G.Q., 2014, Chemical and isotopic constraints on evolution of groundwater salinization in the coastal plain aquifer of Laizhou Bay, China, J. Hydrol., 508, 12-27.

[25] Robinson, C., Gibbes, B., and Li, L., 2006, Driving mechanisms for groundwater flow and salt transport in a subterranean estuary, Geophys. Res. Lett., 33 (3), L.03402.

[26] Aghazadeh, N., and Mogaddam, A.A., 2010, Assessment of groundwater quality and its suitability for drinking and agricultural uses in the Oshnavieh Area, Northwest of Iran, J. Environ. Prot., 1, 30-40.

[27] Etteieb, S., Cherif, S., and Tarhouni, J., 2017, Hydrochemical assessment of water quality for irrigation: A case study of the Medjerda River in Tunisia, Appl. Water Sci., 7, 469-480. 